\title{
Calisto, Leriano, Oliveros: tres dolientes y un mismo grabado
}

\author{
Enrique Fernández Rivera \\ Universidad de Manitoba, Canadá
}

La importancia de los diecisiete grabados (dieciséis más uno repetido) de la supuesta primera edición de La Celestina o Comedia de Calisto y Melibea impresa por Fadrique de Basilea en Burgos en 1499 es indiscutible ya que estas imágenes que escenifican los argumentos que encabezan los actos sentaron la base de toda una larga serie de ediciones ilustradas de la obra en el siglo siguiente (Snow 58-59). No sabemos nada del autor de los grabados, lo que no es de extrañar pues tampoco sabemos a ciencia cierta el nombre de ningún artista o grabador de los libros ilustrados del siglo XV, como señaló Pollard en su clásico trabajo sobre el tema (5-6). Sin embargo, la manufactura de estos grabados ha permitido sacar interesantes conclusiones. Que las planchas de madera con que se imprimieron se realizaron ex professo para este libro es evidente por la especificida y complejidad de los eventos que representan. De su estilo se ha señalado que muestra una clara influencia alemana, lo que es fácilmente explicable dada la procedencia centroeuropea de muchos de los primeros impresores y grabadores que trabajaron en España. Más específic mente, se ha demostrado que el paisaje urbano y algunas figuras de los grabados están copiados de las ediciones ilustradas de las Comedias de Terencio publicadas por Johannes Treschel en Lyon (1493) y por Johann Grüninger en Estrasburgo (1496) (Martín Abad y Moyano Andrés 18; Rodríguez-Solás; Griffin, 66-68) ${ }^{1}$. Sin embargo, estas dos ediciones ilustradas de las obras de Terencio no influyeron en la composición de escena de los grabados de Burgos, que representan acciones específicas de $L a$ Celestina con un detalle y dinamismo que no tienen equivalencia en las ilustraciones de Terencio citadas. Finalmente, otra influencia detectada

1.- Más recientemente, John T. Cull ha mostrado influencias en La Celestina de Burgos del paisaje urbano y las figuras de la traducción alemana del Eunuchus publicado en Ulm en 1486. 
en los grabados de esta primera Celestina es la de la iconografía cristiana, cuyas soluciones tradicionales de composición de grupo se han utilizado en algunos de sus grabados (Fernández Rivera). Sin embargo, no se ha identificado todavía un modelo específico para ninguno de los dieciséis grabados, que es lo que se va a hacer en este artículo. Se mostrará que la parte derecha del grabado que ilustra el acto trece de la edición de La Celestina de Fadrique de Basilea (Fig. 1) es una adaptación de un grabado que se usó en la primera edición ilustrada de Cárcel de amor de Diego de San Pedro, impresa por Pablo Hurus en Zaragoza en 1493 (Fig. 2). A su vez, este grabado de Cárcel de amor es una adaptación de la imagen que, con algunas variaciones, se utiliza varias veces en la primera edición ilustrada de L'histoire d'Olivier de Castille et Artus d'Algarbe, obra caballeresca escrita entre 1430 y 1460 por el francés Philippe Camus e impresa con ilustraciones por Louis Cruse (Ginebra, 1492) (Figs. 6 y 7 ).

Como es el caso de las otras imágenes que ilustran los actos de la edición burgalesa de la Comedia de Calisto y Melibea, la que ilustra el acto trece es un grabado impreso con un bloque de madera, o xilografía, que cubre todo el ancho de página y está situado debajo del argumento del acto, cuya acción intenta escenificar (Fig. 1). El texto del argumento que ilustra lee así:

Despertado Calisto de dormir, está hablando consigo mismo. Dende a un poco está llamando a Tristán y a otros sus criados. Torna a dormir Calisto. Pónese Tristán a la puerta. Viene Sosia llorando. Preguntado de Tristán, Sosia cuéntale la muerte de Sempronio y Pármeno. Van a decir las nuevas a Calisto, el cual, sabiendo la verdad, hace gran lamentación. $(263)^{2}$

El grabado escenifica la primera parte de este argumento, es decir, la llegada de Sosia con las tristes nuevas, mientras Calisto duerme en su aposento. Para ilustrar estas acciones, el grabador recurre a dividir el grabado en dos paneles. Esta técnica de separar en dos o más partes un grabado es muy frecuente en las ilustraciones de la época, que, siguiendo la tradición de la pintura medieval, tratan el espacio de manera más simbólica que realista ${ }^{3}$. Baste como testimonio de lo extendido de tal práctica esta mis-

2.- Las referencias son por número de página a la edición de Crítica que se cita en la bibliografía.

3.- Hablando del grabado del acto ocho, también dividido en dos, Rodríguez-Solás dice que esta técnica de dividir en dos «es una característica de la economía con la que el grabador trataba de ilustrar el dinamismo escénico que se percibe en el texto de La Celestina. Las entradas y salidas de personajes y las figuras que se mueven en varios planos conectan las diversas escenas del acto que se ilustran simultáneamente en el mismo grabado. Su relación con una representación escénica es total y no podemos pensar en otra obra a la que el impresor pudiera acudir que las comedias de Terencion (15). 
ma edición de La Celestina, que recurre a una división similar en dos mitades en diez de sus dieciséis grabados. En ellos, la separación del grabado en dos se realiza mediante un muro, con o sin una puerta, que comunica con la otra mitad del grabado, o mediante una línea vertical que divide artificialmente el plano en dos. Las dos escenas resultantes pueden representar eventos simultáneos en el tiempo y contiguos en el espacio, o bien eventos que tienen lugar en momentos diferentes y en lugares distantes pero que se representan lado a lado por licencia artística. En el grabado del acto trece, las dos escenas están separadas por un muro con puerta, de manera realista, pues se supone que son contiguas y simultáneas. La de la parte izquierda representa a Tristán a la puerta de la casa de Calisto recibiendo a Sosia, quien trae las tristes nuevas de la ejecución de Pármeno y Sempronio. La parte derecha muestra la habitación donde Calisto yace despierto en su cama. Aquí se ha tomado el grabador una pequeña licencia artística al hacer que la puerta del dormitorio de Calisto dé directamente a la calle. Esta disposición contradice la evidencia implícita en unas palabras de Tristán de las que se desprende que la habitación de Calisto no está a nivel de calle, sino en el segundo piso: "TRISTÁn: Quiero bajarme a la puerta por que duerma mi amo sin que ninguno lo impida» (264-65). Otra libertad que se ha tomado el grabador es hacer de una de las paredes de la habitación de Calisto una cuarta pared, en el sentido teatral del término, es decir, una pared transparente que permite a los espectadores ver a través de ella. Este es un recurso muy frecuente en los grabados de la época. Como ejemplo podemos utilizar, una vez más, esta misma edición de La Celestina, en la que once de sus dieciséis ilustraciones incluyen muros transparentes.

Si exceptuamos estas dos licencias artísticas en el tratamiento del espacio, el grabado es fiel al texto del argumento del acto. La escena representada en el lado izquierdo del grabado presenta a Tristán a la puerta de la casa, donde hace guardia para que nadie despierte a su amo, quien, cansado tras la noche de amor con Melibea, quiere seguir durmiendo hasta la hora de comer. Colocar a un personaje delante de una puerta es una convención que sirve, entre otros usos, para representar el recibimiento de un personaje, Sosia en este caso. El grabado muestra la reacción de Tristán al enterarse por el recién llegado Sosia de la ejecución de Pármeno y Sempronio. Su sorpresa está representada en los gestos de manos y brazos. Éstos ofrecían una excelente forma de expresar las emociones en los grabados de los primeros libros impresos, en los que era difícil representar las sutilezas de las facciones del rostro por la dificultad de ejecutar líneas finas en madera que soportaran el desgaste de la impresión repetida. Además, existía un rico lenguaje corporal codificado por el arte medieval para que el público, mayoritariamente analfabeto, reconociera acciones y personajes en cuadros y estatuas que servían como instrumentos didácticos de la doctrina religiosa. Varios gestos de este lenguaje corporal se pue- 
den identificar fácilmente en la representación de este encuentro entre los dos criados a la puerta de la casa de Calisto, donde Sosia es retratado realizando el gesto típico del luctus de levantar los brazos para clamar al cielo o mesarse los cabellos (Garnier 223-26). Aunque sus manos no tocan los cabellos, los del lado izquierdo están representados como puntas afiladas para sugerir su descompostura. Estos cabellos desaliñados son aludidos por Tristán, quien se dice a sí mismo al ver llegar a Sosia: «Desgreñado viene el bellaco; en alguna taberna se debe haber revolcado». Cuando Sosia ya ha llegado hasta él, se da cuenta de que sus cabellos desgreñados y su excitación tienen otro origen: "¿Qué es? ¿Qué has? ¿Por qué te matas? ¿Qué mal es éste?» (265). Probablemente éste es el instante preciso que quiere retratar el grabador al presentar a Tristán volviendo las manos hacia Sosia en gesto de sorpresa.

Mientras tiene lugar este encuentro a la puerta de la casa, en su interior Calisto yace en la cama. Su dormitorio ocupa algo más de la mitad derecha del grabado. La figura de Calisto es algo mas grande que las de Sosia y Tristán, aunque esta desproporción apenas se nota por estar la mayor parte de su cuerpo oculto bajo las sábanas. Está recostado sobre su lado izquierdo, su mejilla apoyada en la mano y los ojos abiertos. Viste una camisa de noche y un gorro de dormir a modo de turbante atado al frente. La cama tiene un baldaquino o dosel, que un error de perspectiva en la ejecución del grabado hace aparecer no encima, sino detrás de la cama, un detalle al que volveremos luego. Un detalle significativo, como también se verá más adelante, es el bucle de tela que cuelga de uno de las esquinas del baldaquino de la cama. En primer plano a mano derecha hay una pieza de mobiliario pequeña cuya naturaleza apenas puede dilucidar dado su esquematismo. El rayado en negro que cubre la mayor parte de la habitación a manera de sombreado sugiere la oscuridad reinante. Sin embargo, la ventana situada detrás de la cama está abierta y deja pasar la luz. Este detalle parece contradecir la orden expresa de Calisto a Tristán de que vuelva a cerrar la ventana, pero probablemente se incluye como alusión a la acción del criado de abrir brevemente la ventana para mostrarle a su amo que ya hace tiempo que es de día.

La imagen de un Calisto que reposa con los ojos abiertos y la cabeza apoyada en su antebrazo es casi idéntica a la de Leriano enfermo de amor en un grabado de la edición zaragozana de Cárcel de amor impresa por $\mathrm{Pa}$ blo Hurus en1493 (Fig. 2). Ésta es la primera edición ilustrada de Cárcel de amor, aunque no la primera de la obra, que había aparecido impresa por primera vez, sin ilustraciones, en Sevilla, $1492^{4}$. De la edición ilustrada de Zaragoza se conserva un solo ejemplar incompleto que se descubrió en el

4.- Aunque la primera edición impresa de Cárcel de amor de Sevilla de 1492, de la que se conserva un solo ejemplar, carece de grabados, Deyermond argumenta que tenía un grabado en la portada, hoy perdida, y que sería el mismo que se reproduce en la edición de Zaragoza de 1493 y otras posteriores. 
Archivo Histórico de Protocolos de Zaragoza. Está fechado a 4 de junio de 1493 y, aunque no figura el nombre del impresor, Pallarés Jiménez lo identificó como producto de la imprenta de Pablo Hurus por la tipografía y otras características. Las páginas conservadas contienen once grabados, que coinciden con los correspondientes de los dieciséis de la traducción catalana de la misma obra, impresa algo más tarde el mismo año por Rosenbach en Barcelona y que se consideraba la edición más antigua con ilustraciones de Cárcel de amor hasta el descubrimiento del ejemplar zaragozano ${ }^{5}$. Entre los grabados que ilustran tanto la edición de Zaragoza como la de Barcelona hay uno que representa el episodio de la enfermedad de amor de Leriano conocido como el planctus de la duquesa Coleria, la madre de Leriano. El grabado está colocado directamente encima de las siguientes palabras de Coleria:

$¡ \bigcirc$ alegre descanso de mi vegez! $¡ \bigcirc$ dulce hartura de mi voluntad! Oy dexas de dezirte hijo y yo de más llamarme madre, de lo qual tenía temerosa sospecha por las nueuas señales que en mí vi de pocos días a esta parte [...] hasta los animales me certificauan tu mal; saliendo vn día de mi cámara vínose vn can para mí y dio tan grandes avllidos, que assí me cortó el cuerpo y la habla. (201)

El grabado representa a Coleria lamentándose a los pies de la cama de su hijo Leriano a manera de una Dolorosa al pie de la cruz. La curiosa inclusión de un perro muerto es una curiosa materialización de su referencia a los aullidos premonitorios de un can (Cacho Blecua, "Los grabados» 371).

Esta imagen de Leriano con su madre a los pies de la cama y el can muerto es una de las tres que lo representan mortalmente enfermo de amor en su lecho en la edición ilustrada de Cárcel de amor de Zaragoza. Las otras dos son los grabados que se reproducen en las Figs. 4 y 5 , que ilustran otros dos importantes episodios de la agonía de Leriano. La Fig. 4 lo muestra enumerando las razones por las que los hombres están obligados a las mujeres. La Fig. 5 lo retrata troceando las cartas de Laureola en un vaso de agua que luego se beberá. Estos dos grabados utilizan también como escenario el dormitorio de Leriano, aunque el mobiliario cambia ligeramente. La diferencia más notable es la presencia de un baldaquino circular en el grabado en que Leriano rompe las cartas, lo que refuerza la sugerencia de una ceremonia religiosa en la que va a beber de un cáliz (Fig. 5). Estos tres cuadros tan impactantes como similares en diseño de un Leriano doliente debieron venirle a la memoria al grabador burgalés cuando tuvo que ilustrar a un Calisto en su cama, que, aunque no estaba propiamente enfermo de amor en ese episodio, lo había estado en otros anteriores.

\section{5.- Pallarés Jiménez. Véase también Fraxanet Sala.}


La Fig. 3 es una composición en la que hemos invertido la figura de Leriano con la ayuda del ordenador y la hemos colocado junto a la de Calisto para resaltar el gran parecido entre ambas. En este montaje se ve claramente que el grabado de La Celestina es un calco del de Cárcel de amor. Lógicamente, Coleria y el perro muerto han desaparecido de la habitación de Calisto, pero los demás elementos son prácticamente los mismos. Especialmente parecidas son las figuras de Calisto y Leriano, ambos en cama, sus cabezas apoyadas en la palmas de las manos, con los ojos abiertos y vistiendo ropas y gorros de dormir similares. Mientras que en el original Leriano apoya la cabeza en su mano derecha, en la copia Calisto lo hace en la izquierda por inversión resultante del proceso de calco. Este método de copia directa, sin embargo, trajo consigo un problema de proporciones dado que el marco del grabado de La Celestina es menor que el de Cárcel de amor. Mientras que el grabado de La Celestina mide apenas $60 \mathrm{~mm}$ de alto, el de Cárcel de amor alcanza los $95 \mathrm{~mm}$. Tales dimensiones responden a que los grabados de La Celestina tienen un formato apaisado, mientras que los de Cárcel de amor son cuadrados, incluso un poco más altos que anchos, como en un formato de retrato. El grabador no podía cambiar estas medidas y proporciones pues tenía que acomodarse a lo acordado con el impresor para que éste pudiera componer la plana. El grabador burgalés se vio pues forzado a introducir la figura calcada de Leriano en un marco de menor altura que el original, lo que resultó en que su Calisto estuviera a una escala algo mayor que Sosia y Tristán. Estas dos figuras no las podía dibujar a la misma escala que la de Calisto porque, al estar ambos personajes de pie, alcanzarían el tope superior del marco. Sin embargo y como dijimos, este problema de desproporción resultó ser casi imperceptible por estar Calisto tumbado y parcialmente cubierto por las sábanas. Pero si bien su figura apenas se modificó, el mobiliario de su dormitorio sufrió cambios para adaptarlo al nuevo marco de altura reducida. Así, el grabador burgalés bajó el baldaquino, que quedó más próximo a la cama que en el modelo original. Con la misma intención y también para dejar más espacio en el margen izquierdo, donde se retrata el encuentro entre Sosia y Tristán, acortó la cama de Calisto, colocándola en plano sesgado. Sin embargo, al reposicionar el baldaquino y la cama cometió el error de perspectiva antes señalado que hace que éste parezca estar detrás y no encima de la cama.

El grabador realizó también otras modificaciones menores para ahorrar espacio en la habitación de Calisto, como mover la ventana hacia la cabecera de la cama y simplificarla. Igualmente, estilizó, hasta el punto de hacerla irreconocible, la compleja mesita de noche de Leriano, de la que retiró la botella y el vaso. Otros cambios que el grabador burgalés introdujo no se deben a problemas de espacio ni son simplificaciones de diseño. Al contrario, la camisa de noche de Calisto es más elaborada que la de Leriano pues tiene una abertura en el pecho de la que ésta carece. 
Igualmente, el gorro de dormir de Calisto, aunque es muy parecido al de Leriano, incluye un nudo en la frente. Este detalle elimina la apariencia del tocado de Leriano de ser una venda enrollada en torno a su febril cabeza. Otra modificación sutil pero significativa introducida por grabador burgalés es un cambio en el ángulo del brazo doblado sobre el que Leriano se apoya. Reposar la cabeza sobre la palma de la mano en los cuadros y estatuas del medievo y renacimiento indica dolor o tristeza, ensueño o visión, o simplemente descanso, dependiendo de si el personaje tiene los ojos abiertos o cerrados, o del contexto (Garnier 181-84). En el caso de Leriano, su cabeza apoyada en la palma de la mano, junto con los ojos abiertos, el tronco ligeramente incorporado y su madre llorando a los pies de la cama, indican claramente tristeza y dolor. Calisto, también con los ojos abiertos y la cabeza reposando en la palma de la mano, está sin embargo solo en la habitación. Además, el ángulo de su antebrazo es más abierto que el de Leriano, lo que resulta en que su torso parezca estar tumbado, en la posición de descansar con la mano entre la oreja y la almohada. Todos estos cambios hacen que el enamorado doliente se haya convertido un amante cansado tras haber cumplido sus deseos la noche anterior. Calisto, volviendo a dormirse hasta la hora de comer, parece estar recordando los buenos momentos de la noche anterior. El fatal sufrimiento de amor de Leriano se ha convertido en cansancio y vaga melancolía en Calisto ${ }^{6}$.

Si bien es evidente que el grabador burgalés partió del Leriano enfermo para su imagen de Calisto del acto trece, no sabemos si usó la edición ilustrada de Cárcel de amor de Zaragoza (o su traducción al catalán del mismo año) u otra. Lo más lógico es pensar que acudiera a la edición ilustrada de Cárcel de amor que tenía más fácilmente a su disposición y ésa sería la edición de Cárcel de amor que Fadrique de Basilea mismo había publicado en 1496, cuyas ilustraciones son copia exacta de las de Zaragoza y Barcelona. El que Fadrique de Basilea copiara los grabados de Pedro Hurus para su edición de Cárcel de amor se explica fácilmente por las conocidas relaciones comerciales existentes entre ambos (Cacho Blecua, "Los grabados» 368). Semejante contacto entre impresores puede estar relacionado con el hecho de que Hurus había nacido en Constanza, no lejos de la Basilea de Fadrique.

Esta conexión suiza de la edición de Burgos se extiende aún más. Como ya apuntamos, los grabados de la edición de Hurus de Cárcel de amor fueron realizados expresamente para esta edición, pero eso no quita que algunos de ellos se inspiraran en modelos anteriores. Así, creemos poder probar que los tres grabados de la muerte de Leriano de la edición de Cár-

6.- Estos cambios del grabado de Leriano enfermo de amor no hubieran sido necesarios si la imagen se hubiera usado para ilustrar la escena del acto segundo de La Celestina, cuando Calisto está encerrado en su habitación quejándose de su amor no correspondido por Melibea. 
cel de amor de Hurus están basados en ilustraciones de L'histoire d'Olivier de Castille et d'Artus d'Algarbe impresa en Basilea en 1492 por Louis Cruse. También conocido como Alouis Guerbin, Guerbini, o Garbin de la Cruse, este impresor nacido en Ginebra es uno de los más importantes de la época. Entre los libros que publicó se incluye una serie de ediciones ilustradas de las aventuras de Olivier de Castille. Es éste un libro de caballerías escrito en el segundo tercio del siglo Xv por Philippe Camus, personaje ligado a la corte ducal de Borgoña. El libro tuvo una importante circulación manuscrita y se imprimió por primera vez en Basilea en 1482. Entre 1492 y 1497, Louis Cruse imprimió seis ediciones ilustradas (Gaullieur 39, 51; Lökkös 20). Entre los grabados que ilustran estas ediciones, dos sirvieron de modelo para el grabado zaragozano de Leriano yacente con la cabeza reposando en la palma de la mano (Figs. 6 y 7). El grabado reproducido en la Fig. 6 representa a Artus d'Algarbe, hermanastro y amigo inseparable de Olivier de Castille, sin sentido en la cama de la habitación de Olivier tras haber encontrado una carta de despedida que éste le ha dejado. La escena representa a Artus ya vuelto en sí, lamentándose, mientras el rey, que ha acudido en su ayuda, procede a leer la carta de Oliveros. El grabado de la Fig. 7, muy similar, muestra a Olivier enfermo de amor por la princesa Hélène, quien, enterada de su dolencia, ha venido a visitarlo con reducido sequito. La parte derecha de estas dos imágenes son casi idénticas pues las figuras usadas para representar a Artus y Olivier son las mismas. Las habitaciones también coinciden, excepto en detalles de la cama y de una ventana ausente en el segundo grabado. Nótese también la presencia del bucle de tela colgado del baldaquino en ambos grabados que llegará hasta el dormitorio de Calisto.

El templete de un personaje en una cama con baldaquino del que cuelga un bucle de tela reaparece en otras cuatro ocasiones en esta edición ilustrada de L'histoire d'Olivier de Castille de Louis Cruse, aunque los personajes yacentes cambian. Las Figs. 8, 9, 10 y 11 repiten el mismo templete: la Fig. 8 representa a Artus gravemente enfermo en cama visitado por Olivier; la Fig. 9 muestra a Olivier tras ejecutar a sus hijos por mandato divino para curar a Artus ; la Fig. 10 es la de Olivier ofreciendo la sangre de los niños a Artus. La más curiosa de estas seis imágenes de personajes en un cama con baldaquino y bucle de tela en este libro de Louis Cruse es la Fig. 11, que representa a la reina visitada por el rey y su sequito tras el parto de Olivier. De manera incongruente, se muestra al recién nacido Olivier como un niño de varios años, de pie junto a la cama. Esta inconsistencia se explica porque este grabado se diseñó originalmente para ilustrar una escena de Les sept sages de Rome, libro impreso también en Basilea en 1492 por Louis Cruse y del que L'histoire d'Olivier toma varias ilustraciones, entre ellas ésta. En su contexto original de Les sept sages de Rome, esta imagen de una reina y un niño ilustra la historia de Dioclecianus, a quien, a la edad de siete años, su madre, en su lecho, de muerte, 
encomendó a su padre, el emperador Poncianus, para que fuera educado por los Siete Sabios.

Dejando de lado todos estos interesantes detalles, lo importante para nuestra argumentación es que el grabado del Olivier como doliente de amor sirvió de modelo para la edición ilustrada de Cárcel de amor de Hurus de Zaragoza. El grabador zaragozano utilizó el templete de la habitación y la cama con baldaquino de L'histoire d'Olivier para las tres escenas en que Leriano yace enfermo de amor en su lecho (Figs. 2, 4 y 5). El parecido más evidente es entre los dos grabados que representan respectivamente a Artus y Olivier recostados en la cama, la cabeza apoyada en la mano (Figuras 6 y 7), y el grabado que muestra a Leriano en la misma posición, con su madre llorando a sus pies (Fig. 2). El hecho de que este grabado de Leriano yacente sea el único de los tres que está girado respecto a su modelo sugiere que fue un calco directo. El que los otros dos grabados de Leriano enfermo - Leriano defendiendo a las mujeres (Fig. 4) y Leriano a punto de beberse las cartas de Laureola (Fig. 5) — indica que la cama con baldaquino y demás elementos comunes no se calcaron directamente de L'histoire d'Olivier sino a partir del grabado de Leriano yacente y su madre a sus pies, ya girado por el calco (Fig. 2). Éste sería así el primero en ser ejecutado y serviría de plantilla para las otras dos escenas de Leriano yacente, en las que el giro desaparece por efecto de ser calcos de un calco. Lógicamente, el grabador de la Cárcel de amor zaragozana omitió personajes y otros detalles que no encajaban con el nuevo contexto. También modificó algunos detalles del original, como transformar a los dolientes Olivier y Artus, que yacían vestidos encima de la cama, en un Leriano con ropa y gorro de dormir bajo las sabanas. Todas estas innovaciones pasaron al Calisto yacente de La Celestina.

Curiosamente, esta historia de copias y calcos de grabados es continuada en la Historia de Oliveros de Castilla y Artús d'Algarbe impresa por el mismo Fadrique de Basilea en 14997. Los grabados de la las aventuras de Oliveros de la edición de Fadrique de Basilea, sin ser calcos de los grabados de Louis Cruse, están claramente inspirados en ellos, aunque son más elaborados que su modelo. Su mayor nivel de detalle se puede ver si comparamos el grabado con que se ilustra el desmayo de Artús tras leer la carta de despedida de Oliveros en la edición española de Fadrique de Basilea (Fig. 12) con su equivalente en la edición de Louis Cruse (Fig. 6). A pesar de la mayor elaboración del grabado burgalés, es fácil reconocer la misma cama, baldaquino con colgante, ventana y doliente con la cabeza apoyada en la palma de la mano de Louis Cruse. Un cambio introducido por el grabador burgalés es muy interesante por lo que implica. Si com-

7.- Los cambios que la historia sufrió tanto en el paso de su etapa manuscrita a su etapa impresa, así como del original francés al español, se pueden ver en Miguel Ángel Frontón «Del Olivier» y "La difusión». Un análisis más reciente es el de Pairet. Véase también Cacho Blecua, «De la Histoire d'Olivier». 
paramos al Olivier doliente visitado por Hélène de Louis Cruse con el Oliveros del grabado equivalente en la versión española de Fadrique de Basilea (Figs. 7 y 13), sorprende descubrir que éste último no está tumbado encima de la cama con ropas formales, como en el original francés, sino que lleva la camisa y el gorro de noche del Leriano zaragozano (Figs. 2, 4 y 5). Ha habido pues una curiosa contaminación en el grabado de la edición burgalesa de las aventuras de Oliveros entre las figuras del Olivier de Louis Cruse (Figs. 6 y 7 ) y las posteriores del Leriano de Pablo Hurus (Figs. 2, 4 y 5). El resultado es que en el grabado de Oliveros enfermo de amor visitado por Helena de Fadrique de Basilea (Fig. 13) casi toda la escena responde al modelo franco-suizo de Olivier, salvo la camisa y gorro de noche, que proceden del Leriano zaragozano. De cosecha propia del grabador burgalés es el simpático detalle de añadir las zapatillas al pie de la cama de Oliveros y las manos juntas en posición de rogar (Fig. 13)

Estamos pues ante un caso curioso de influencias entre grabados de tres obras - L'histoire d'Olivier de Castille (y su traducción al español), Cárcel de amor y La Celestina - que se hibridizan entre sí. Los grabados de personajes enfermos en cama de las aventuras de Olivier que ilustran la edición impresa por Louis Cruse en Basilea en 1492 sirvieron de inspiración para los grabados de Leriano enfermo en la Cárcel de amor publicada por Pablo Hurus en 1493 en Zaragoza. No sabemos exactamente cómo ocurrió este contacto. El hecho de que tanto Louis Cruse como Pablo Hurus fueran suizos permite presuponer que, en algún momento, debió de haber relaciones personales o comerciales entre ellos, aunque su existencia no sea imprescindible para justificar este tipo de copias de imágenes, tan frecuente en la época. Que precisamente los grabados de la historia del enamorado caballero Olivier sirvieran de modelo para los del también caballero y aún más enamorado Leriano no es sorprendente. Como Wardropper señaló, Cárcel de amor no es sino "una novela de caballerías en pequeño, con supresión de las aventuras, hechos de armas y episodios mágicos»"

En 1496, Fadrique de Basilea hizo una edición de Cárcel de amor y utilizó los mismos grabados de Hurus, con quien sabemos tenía relaciones comerciales. Tres años más tarde, en 1499, Fadrique de Basilea imprimió la primera edición española de las aventuras de Oliveros, con grabados que se inspiran en las imágenes de la edición francesa ilustrada de Louis Cruse. La otra fuente de inspiración para las imágenes de este primer Oliveros español son, curiosamente, los grabados del Leriano zaragoza-

8.- Fernández Valladares 114 señala otra curiosa relación entre los grabados de La Celestina y el Oliveros de Castilla de Burgos de1499. Las elaboradas vidrieras que aparecen detrás de los personajes en el acto seis de La Celestina (Fig. 14) son muy parecidas a las cristaleras que se incluyen en la visita de Helena al enfermo Oliveros (Fig. 13). Ni la Cárcel de amor de Zaragoza de 1493, ni la de Burgos de 1496, ni L'histoire d'Olivier de Castille de Louis Cruse de 1493 presentan este tipo de cristaleras.

9.- Wardropper 184. No está de acuerdo con esta apreciación Whinnom 62. 
no, que, a su vez, también se derivaban del Olivier de Louis Cruse. La ropa y el gorro de dormir que el grabador de la Cárcel de amor zaragozana de 1493 había añadido a su Leriano doliente se le colocan ahora al Oliveros de la edición de Burgos de 1499, dandose así un curioso salto atrás en el tiempo al hacer que el personaje original sea influenciado por su adalid. La situación se vuelve aún más interesante al considerar que también en 1499 Fadrique imprimió su Celestina, en la cual adaptó la imagen del Oliveros-Leriano enfermo para representar a un Calisto adormilado en su aposento ${ }^{10}$.

Antes de concluir esta historia de copia y adaptación de grabados se le puede añadir un curioso colofón. En 1507, Cromberger publicó en Sevilla la primera de sus ediciones ilustradas del Oliveros de Castilla, que fue una obra muy popular en España ${ }^{11}$. La imagen del enfermo en cama con baldaquino y gorro de dormir vuelve a utilizarse en un grabado que incluye varios visitantes (Fig. 15). La imagen se repite en el libro de Cromberger para ilustrar cuatro eventos, sin prestar atención a su adecuación al texto que debe ilustrar. Así, se usa el grabado para ilustrar el nacimiento de Oliveros, con lo que el personaje en cama se convierte, de manera incongruente, en la madre de Oliveros - recuérdese que el primer uso de la cama con baldaquino era el parto de Oliveros en la edición de Louis Cruse (Fig. 11). Se repite el mismo grabado una segunda y tercera vez para representar a Artús enfermo y a Oliveros trayéndole la sangre de su hijos para curarle. La cuarta y última reaparición es para ilustrar la enfermedad de amor de Oliveros. Pero lo más curioso es otro grabado - diferente pero claramente basado en el modelo de cama con baldaquino- que se crea para ilustrar el casamiento de la hija de Oliveros con el rey del Algarve (Fig. 16). Este grabado representa la noche de bodas, en la que un ángel, que parece sacado de una Anunciación, levanta el baldaquino de la cama y señala con el dedo a la hija de Oliveros, que junta sus manos en gesto de aceptación. A su derecha en el lecho está su marido, el rey del Algarve, reposando la cabeza sobre la mano y vistiendo el gorro de dormir. Ahora el personaje está desnudo bajo las sábanas, los ojos están cerrados y el ángulo del codo es tal que el rey del Algarve está completamente tumbado, como si descansara tras haber concebido el príncipe heredero que el ángel parece anunciar.

Si recapitulamos, vemos que, en un periodo de veinticinco años (14921507), la imagen de un hombre yacente y con la cabeza apoyada en la palma de la mano que se origina en L'histoire d'Olivier de Castille de Louis

10.- Como la datación exacta de incunables, especialmente en el caso de La Celestina de Burgos, es muy problemática, prefiero no especular sobre si La Celestina precede o sigue al Oliveros de Castilla de Fadrique de Basilea, ambos, teóricamente, impresos el mismo año.

11.- La traducción de L'histoire d'Olivier de Castille tuvo gran éxito en España pues se publicaron más de diez ediciones de diferentes impresores en la primera mitad del siglo Xvi, como señala Corfis 23-37. 
Cruse para representar a Artus y a Olivier ha sido reutilizada y adaptada para representar a Leriano, a Calisto e incluso al rey del Algarve en su noche de bodas. En todos los casos se puede reconocer fácilmente la cabeza descansando en la mano y una cama con baldaquino que tiene uno o más pliegues de tela colgando de una esquina. Pequeños cambios en la vestimenta y en el ángulo del antebrazo, así como la inclusión de otros personajes, permiten que el mismo gesto y postura sirva para representar las más diversas etapas del amor, desde la enfermedad de amor de Leriano y Oliveros hasta el descanso de un Calisto meditativo tras la noche de amor en el jardín de Melibea o el dormir satisfecho del rey del Algarve en su noche de bodas. No hemos encontrado otras utilizaciones de esta plantilla pero es muy probable que existan. Igualmente, aunque el primer uso de este modelo concreto de cama y baldaquino hasta que hemos logrado remontarnos está en L'histoire d'Olivier de Castille de 1492, es posible que éste, a su vez, proceda de un grabado anterior.

Para concluir queremos enfatizar las implicaciones que este proceso de copia y adaptación de grabados tiene para la recepción temprana de La Celestina. Si el parecido de algunas figuras en los grabados de la primera Celestina con las usadas en las comedias de Terencio apuntan a su conexión con el género dramático, la ascendencia directa del grabado del acto trece la relaciona con la novela sentimental y los libros de caballerías, especialmente con el caballero doliente y enamorado que estos dos géneros comparten. La imagen del hombre en cama con la cabeza apoyada en la mano sigue muy de cerca el modelo del enfermo de amor de Leriano y de su antecesor, Oliveros de Castilla. En otras palabras, Calisto es hijo de Leriano y nieto de Oliveros, de los que ha heredado la cama, la postura, incluso la ropa. Esta ascendencia de grabados concuerda perfectamente con la bien conocida relación de la obra de Rojas tanto con la novela sentimental como con el amor cortés.

\section{Bibliografía citada}

Cacho Blecua, Juan Manuel. «De la Histoire d'Olivier de Castille al Oliveros de Castilla: tradiciones y contextos históricos». Medioevo romanzo 30.2 (2006): 349-70.

—. «Los grabados de la Cárcel de amor (Zaragoza, 1493, Barcelona, 1493, y Burgos, 1496): La muerte de Leriano». Actas del XI Congreso Internacional de la Asociación Hispánica de Literatura Medieval. Ed. Armando López Castro y María Luzdivina Cuesta Torre. Vol. 1. León: Universidad de León, 2007. 367-80.

Camus, Philippe. L'histoire d'Olivier de Castille et Artus d'Algarbe. Ginebra: Louis Cruse, 1492. 
-. Historia de Oliveros de Castilla y Artús d'Algarbe. Burgos: Fadrique de Basilea, 1499.

-. Historia de los nobles caballeros Oliveros de Castilla y Artús de Algarbe. Sevilla: Cromberger, 1507.

Corfis, Ivy, ed. Historia de Oliveros de Castilla y Artús d'Algarbe. Madison: The Hispanic Seminary of Medieval Studies, 1997.

Cull, John T. "A Possible Influence on the Burgos 1499 Celestina Illustrations: The German 1486 Translation of Terence's Eunuchus». La Corónica 38.2 (2010): 137-60.

Deyermond, Alan. «The Woodcuts of Diego de San Pedro's Carcel de Amor, 1492-1496». Bulletin Hispanique 104.2 (2002): 511-28.

FerNÁNDEZ RIVERA, Enrique. "La caída de Calisto en las primeras ediciones ilustradas de La Celestina». eHumanista 19 (2011): 137-56.

Fernández VAlLadares, Mercedes. "Biblioiconografía y literatura popular impresa: la ilustración de los pliegos sueltos burgaleses (o de babuines y estampas celestinescas)». eHumanista 21 (2012): 87-131.

Fraxanet Sala, María Rosa. "Estudio sobre los grabados de la novela $\mathrm{La}$ cárcel de amor de Diego de San Pedro". Estudios de iconografía medieval española. Ed. Joaquín Yarza Luaces y Lucrecia Herrero. Bellaterra: Universidad Autónoma de Barcelona, 1984. 429-82.

Frontón, Miguel Ángel. "Del Olivier de Castille al Oliveros de Castilla: análisis de una adaptación caballeresca». Criticón 46 (1989): 63-76.

- "La difusión de Oliveros de Castilla: apuntes para la historia editorial de una historia caballeresca». Dicenda 8 (1989): 27-52.

Garnier, François. Le langage de l'image au Moyen Âge: signification et symbolique. París: Léopard d'or, 1982.

GaUllieUR, Eusèbe-Henri. Études sur la typographie genevoise du $\mathrm{XV}^{e}$ au XIXe siècles et sur l'introduction de l'imprimerie en Suisse. Ginebra: H. Georg, Libr. de L'Institut, 1855.

GrifFin, Clive. "Celestina's Illustrations». Bulletin of Hispanic Studies 78 (2001): 66-68.

LÖKKÖs, Antal. "La production des romans et des récits aux premiers temps de l'imprimerie genevoise». Cinq siècles d'imprimerie genevoise. Vol. 1. Ed. Jean-Daniel Candaux y Bernard Lescaze. Ginebra: Societé d'Histoire et de Archéologie, 1980. 15-30.

Martín Abad, Julián, e Isabel Moyano Andrés. Estanislao Polono. Alcalá de Henares: Universidad de Alcalá, Centro Internacional de Estudios Históricos Cisneros, 2002.

Pairet, Ana. «From Court to Empire: The Peninsular Trajectory of Olivier de Castille». Courtly Arts and the Art of Courtliness: Selected Papers from the Eleventh Triennial Congress of the International Courtly Literature Society. Ed. Keith Busby y Christopher Kleinhenz. Cambridge: D.S. Brewer, 2006. 507-15. 
Pallarés Jiménez, Miguel Ángel. La Cárcel de amor de Diego de San Pedro, impresa en Zaragoza el 3 de junio de 1493: membra disjecta de una edición desconocida. Zaragoza: Centro de Documentación Bibliográfica Aragonesa, 1994

Pollard, Alfred W. Early Illustrated Books: A History of the Decoration and Illustration of Books in the $15^{\text {th }}$ and $16^{\text {th }}$ Centuries. Londres: K. Paul, Trench \& Trubner, 1926.

Rodríguez-SolÁs, David. "A la vanguardia del libro ilustrado: El Terencio de Lyon (1493) y La Celestina de Burgos (1499)». Bulletin of Spanish Studies 86.1 (2009): 1-17.

Rojas, Fernando de. Comedia de Calisto y Melibea. Burgos: Fadrique de Basilea, 1499.

- La Celestina, tragicomedia de Calisto y Melibea. Ed. Guillermo Serés, Francisco J. Lobera, Paloma Díaz-Mas, Carlos Mota, Iñigo Ruiz Arzalluz y Francisco Rico. Barcelona: Crítica, 2000.

San Pedro, Diego de. Cárcel de amor. Sevilla: Cuatro compañeros alemanes, 1492.

- Cárcel de amor. Zaragoza: Pablo Hurus, 1493.

- Cárcel de amor. Tr. al catalán de Bernadí Vallmanya. Barcelona: Johan Rosenbach, 1493.

- Cárcel de amor. Burgos: Fadrique de Basilea, 1496.

Les sept sages de Rome. Basilea: Louis Cruse, 1492.

Snow, Joseph. «La iconografía de tres Celestinas tempranas (Burgos, 1499; Sevilla, 1518; Valencia, 1514): unas observaciones». Estudios sobre "La Celestina». Ed. Santiago López-Ríos. Madrid: Istmo, 2001. 58-82.

Terencio Africano, Publio. Hernach volget ain maisterliche vnd wolgesetzte Comedia zelesen vnd zehören lüstig vnd kurtzwylig [Eunuchus]. Tr. Hans Nythart. Ulm: Conrad Dinckcmut, 1486.

-. Terentii Comoedia sex, a Guidone Juvenale explanatae et a Jodoco Badio, cum annotationis suis, recognitae. Lyon: Johannes Treschel, 1493.

-. Comoediae. Cum directorio vocabulorum, glossa interlineari, et commentaries Donati, Guidonis, et Ascensii. Estrasburgo: Johann Grüninger, 1496.

Wardropper, Bruce W. «El mundo sentimental de la Cárcel de amor». Revista de filología española 37 (1953): 168-93.

Whinnom, Keith. "Introducción crítica». Diego de San Pedro, obras completas II, Cárcel de amor. Ed. Keith Whinnom. Madrid: Castalia, 1971. 7-66. 


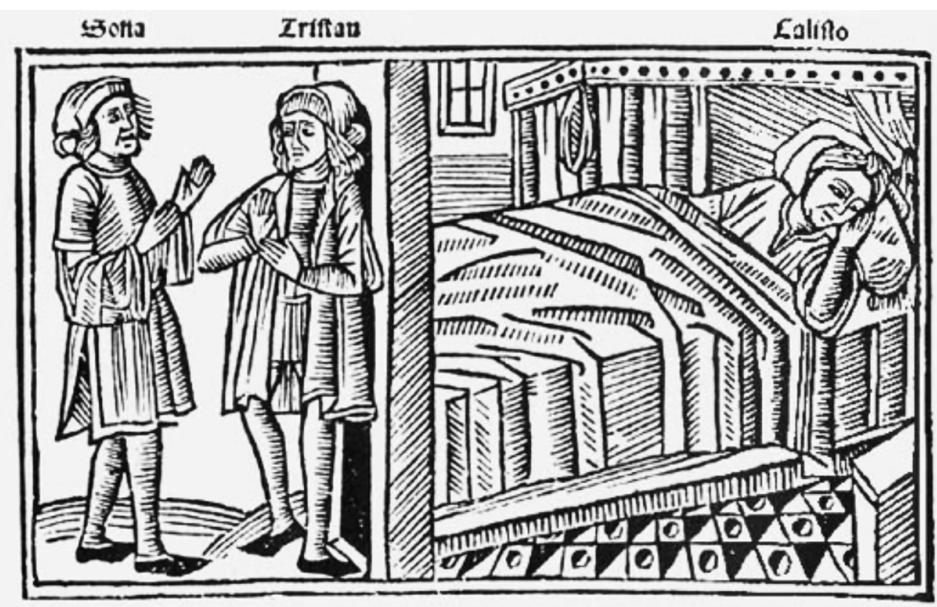

Fig. 1.

Sosia le anuncia a Tristán la muerte de Pármeno y Sempronio mientras Calisto dormita en su habitación (acto trece de La Celestina, Fadrique de Basilea, Burgos, 1499).

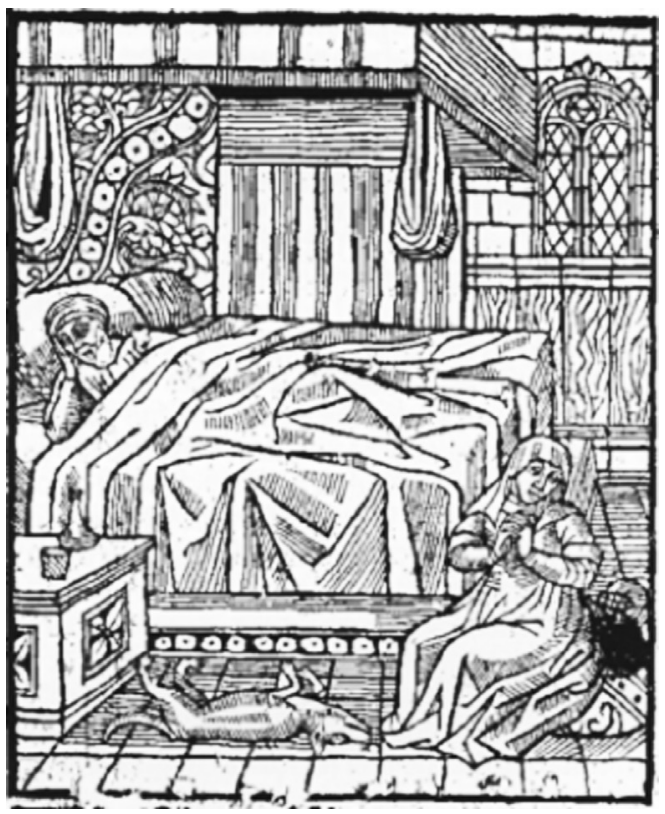

Fig. 2 .

Leriano mortalmente enfermo de amor en su lecho, con su madre a sus pies y un perro muerto (Cárcel de amor, Pablo Hurus, Zaragoza, 1493). 


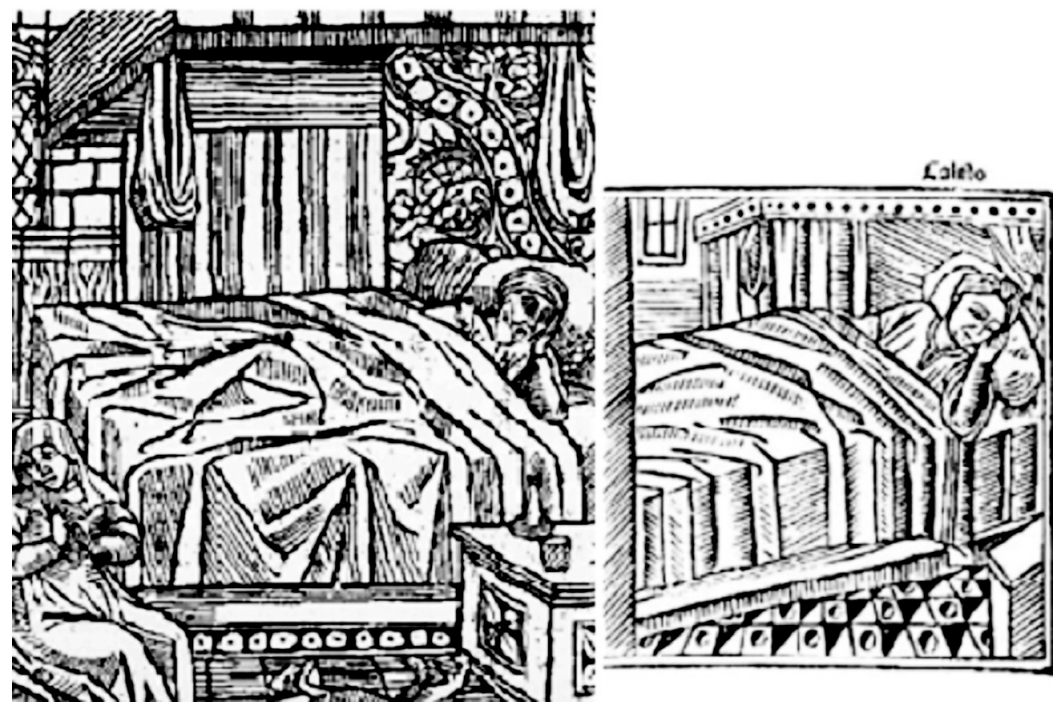

Fig. 3.

Composición de dos detalles de las Figs. 1 y 2, que muestran respectivamente a Calisto (Burgos 1499) y Leriano (Zaragoza, 1493). Hemos girado la imagen de Leriano de derecha a izquierda con el ordenador para remarcar el parecido entre ambos grabados.

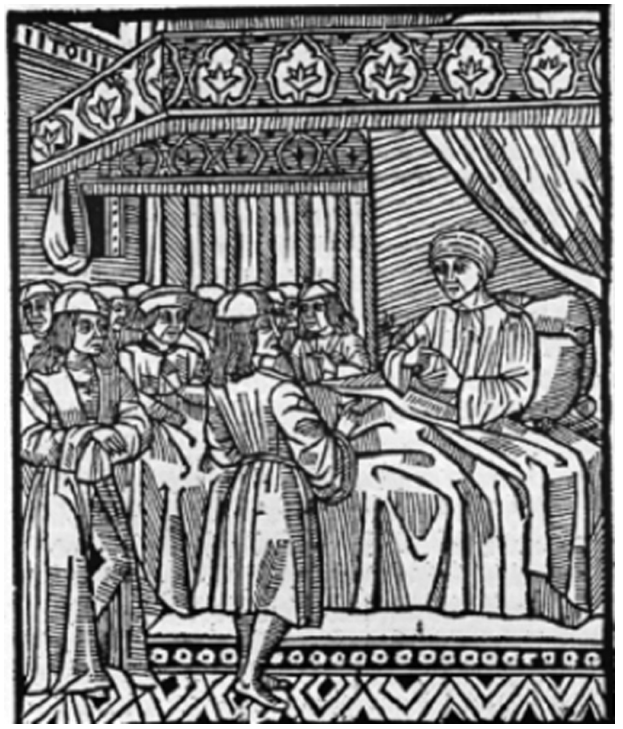

Fig. 4.

Leriano defiende a las mujeres enumerando las razones por las que los hombres les están obligados (Cárcel de amor, Pablo Hurus, Zaragoza, 1493). 


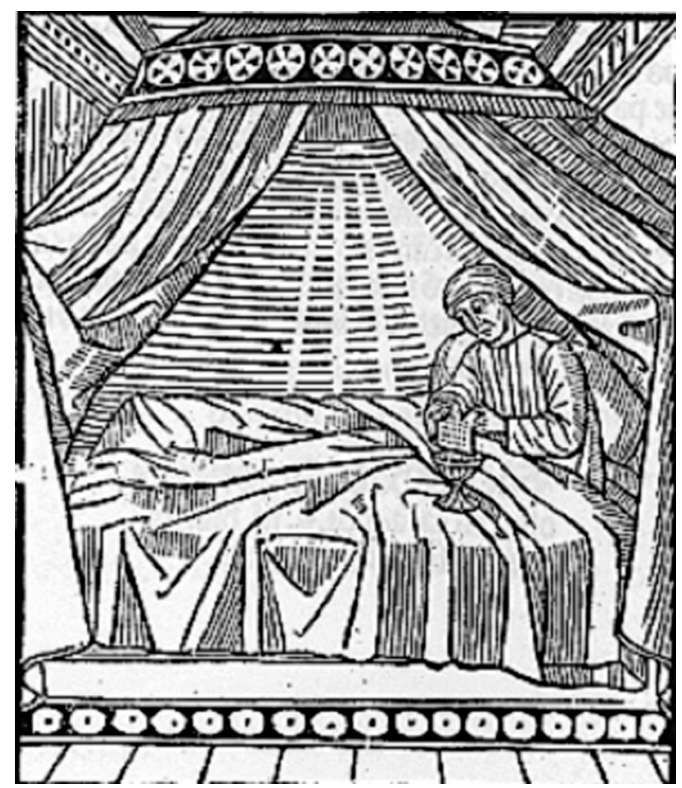

Fig. 5 .

Leriano rompe las cartas de Laureola y las disuelve en un vaso para bebérselas (Cárcel de amor, Pablo Hurus, Zaragoza, 1493).

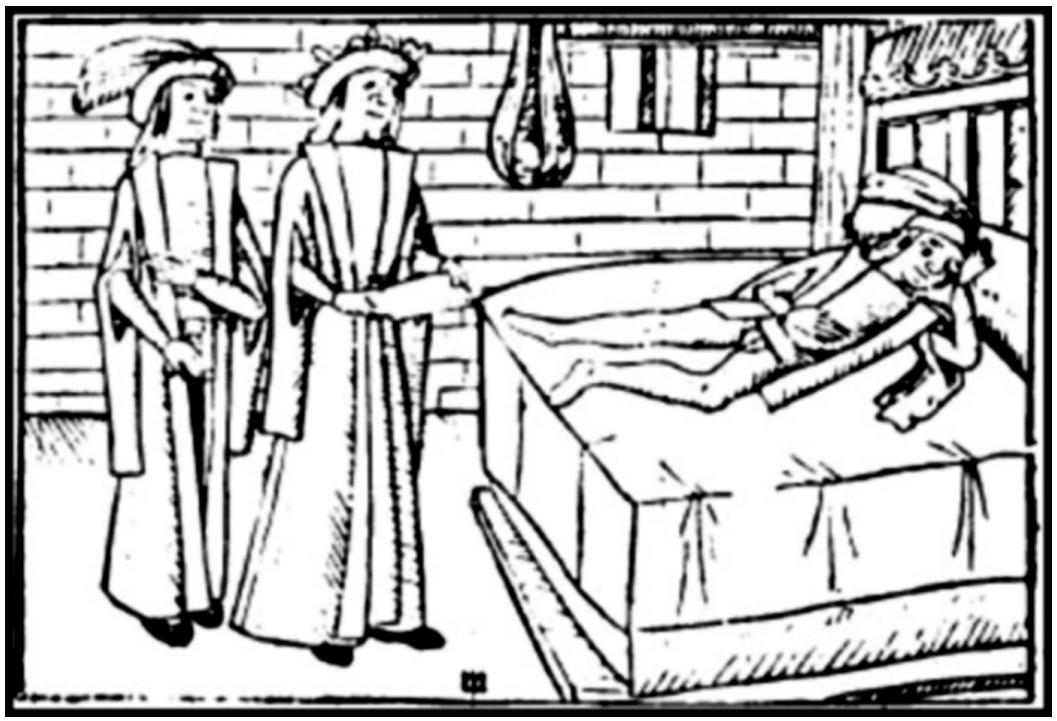

Fig. 6.

Artus desmayado en la cama de Olivier tras haber leído su carta de despedida, que el rey procede a leer (L'histoire d'Olivier de Castille, Louis Cruse, Basilea,1492). 


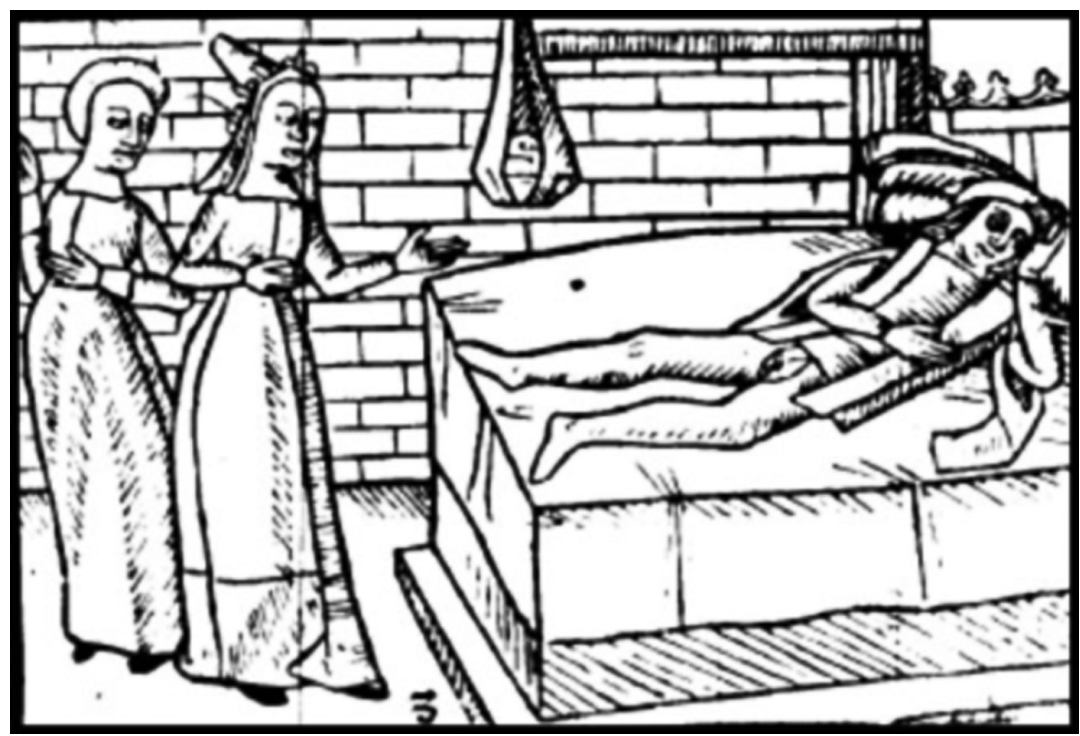

Fig. 7.

Olivier, enfermo de amor por Hélène, es visitado por ésta, acompañada de una de sus damas (L'histoire d'Olivier de Castille, Louis Cruse, Basilea,1492).

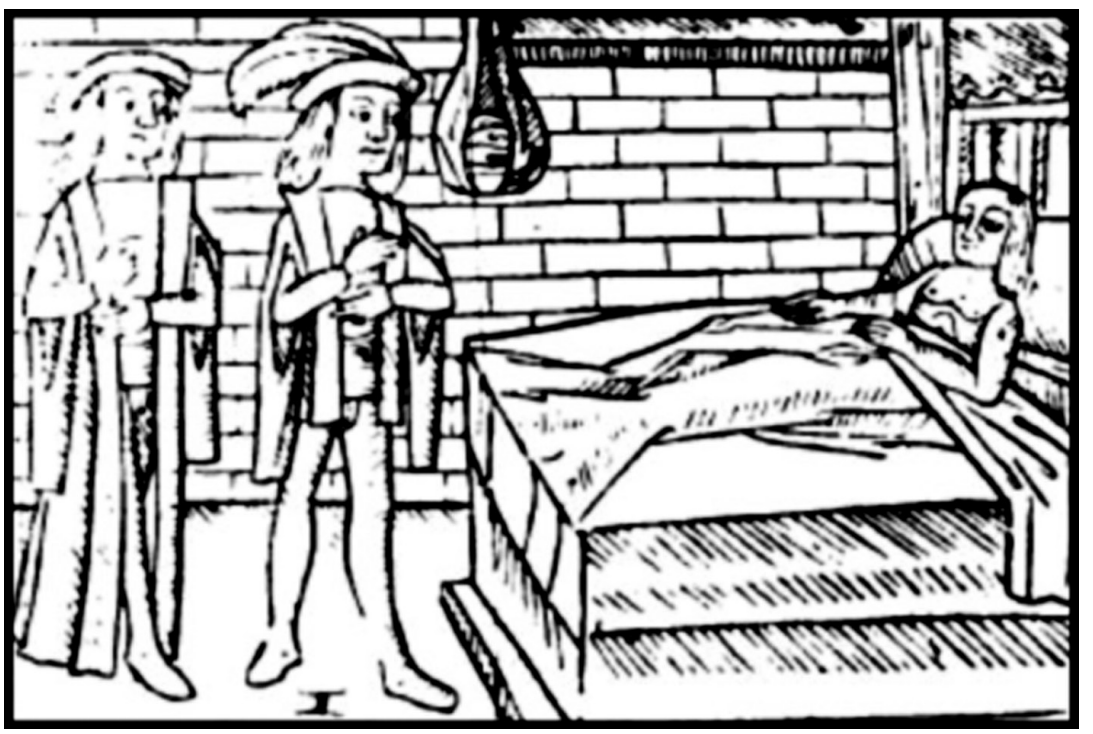

Fig. 8.

Olivier y un acompañante visitan a Artus, que ha caído gravemente enfermo en Londres (L'histoire d'Olivier de Castille, Louis Cruse, Basilea,1492). 


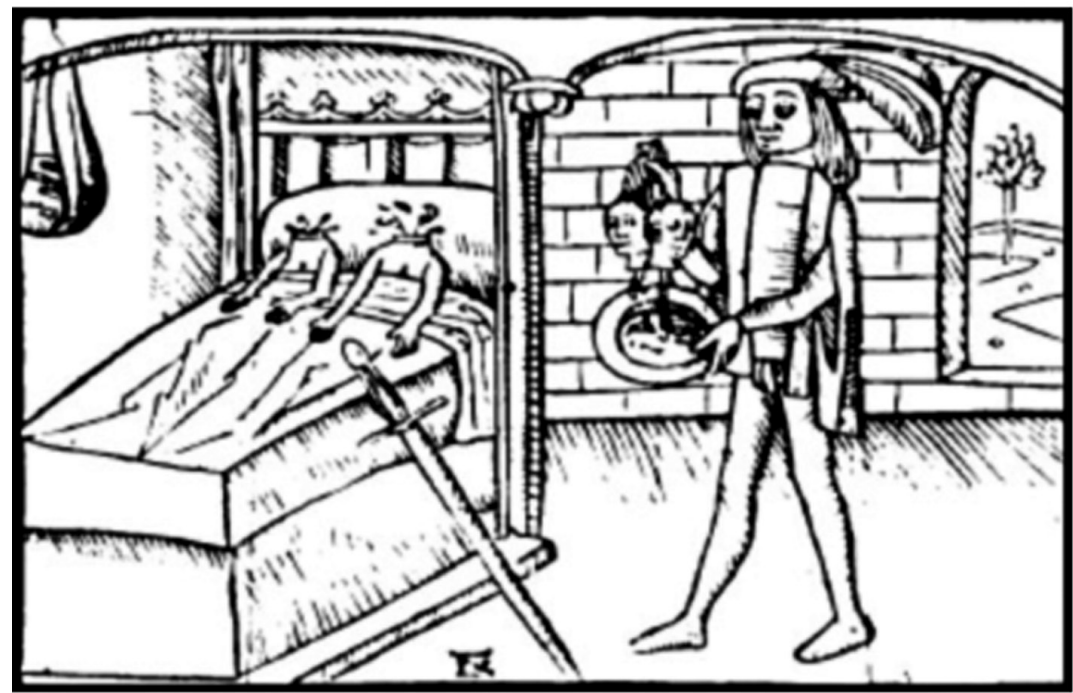

Fig. 9.

Olivier mata a sus hijos para obtener la sangre con la que, según mensaje divino, se curará Artus (L'histoire d'Olivier de Castille, Louis Cruse, Basilea,1492).

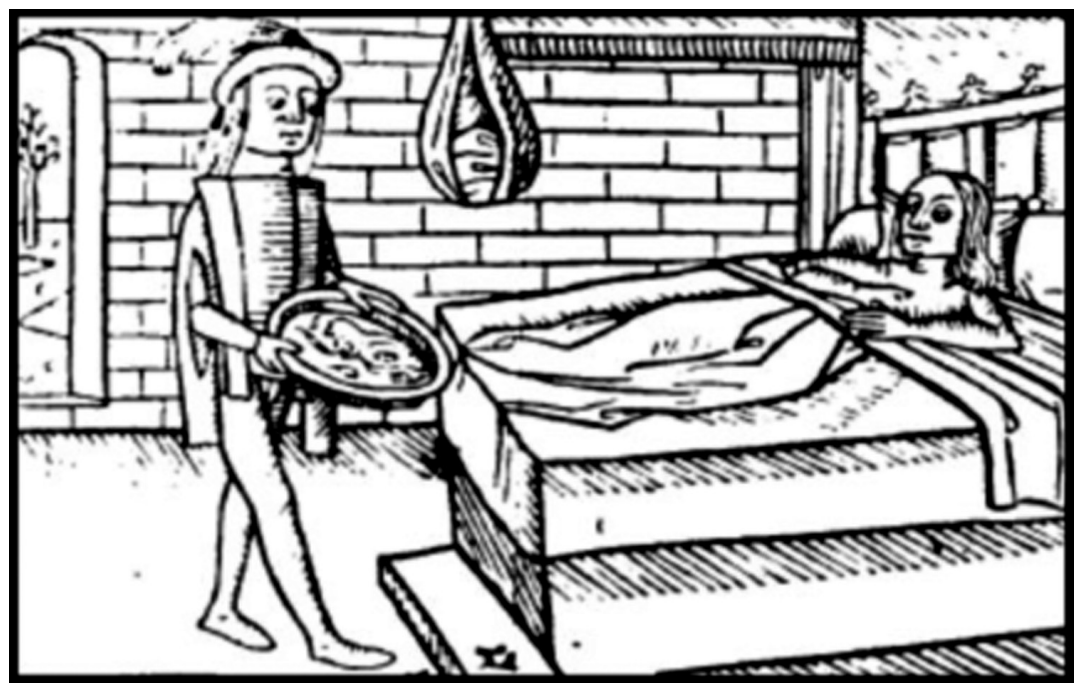

Fig. 10.

Olivier trae la sangre de sus hijos a Artus (L'histoire d'Olivier de Castille, Louis Cruse, Basilea,1492). 


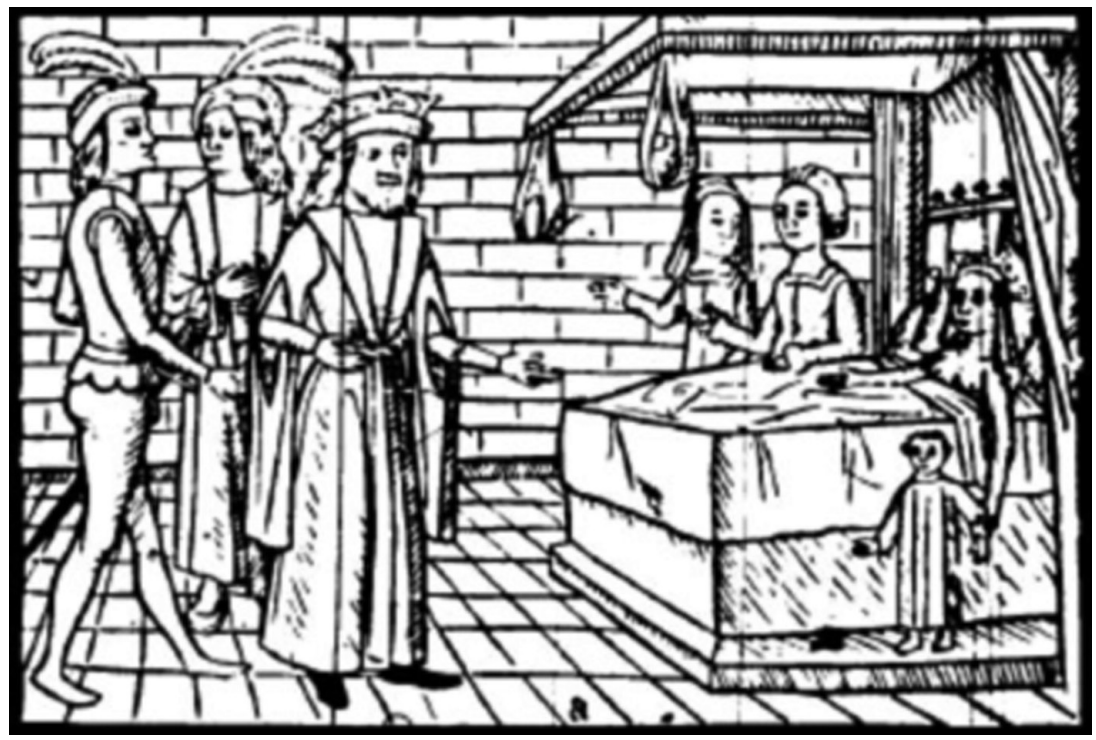

Fig. 11.

Visita del rey a la reina tras el nacimiento de Olivier (L'histoire d'Olivier de Castille, Louis Cruse, Basilea,1492).

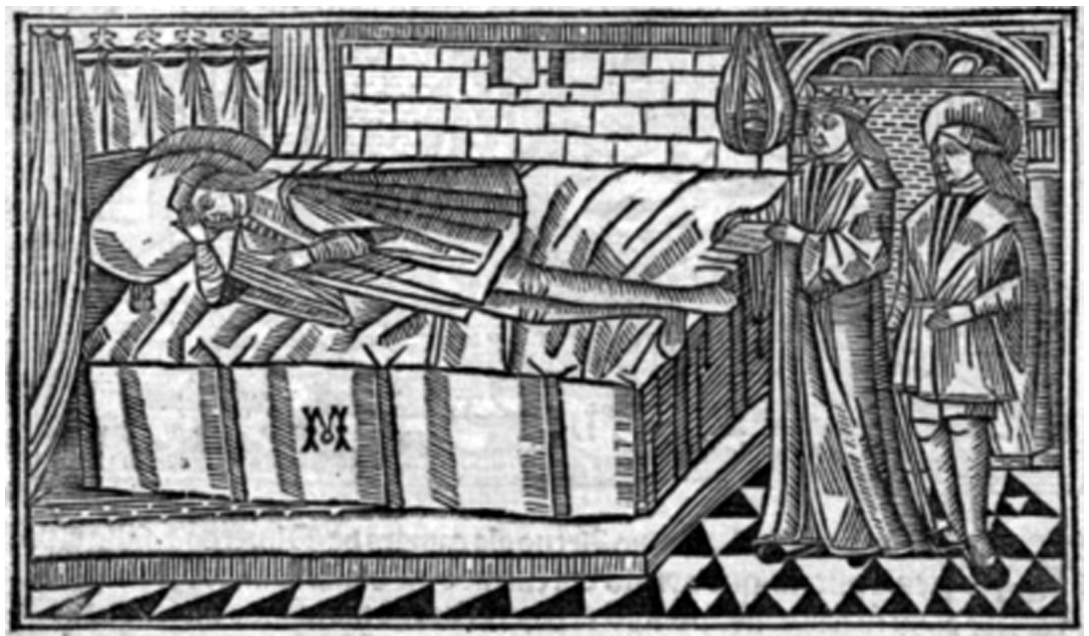

Fig. 12.

Versión española de la Fig. 6, que presenta a Artús desmayado en la cama de Oliveros tras haber leído su carta de despedida (Oliveros de Castilla, Fadrique de Basilea, Burgos, 1499). 


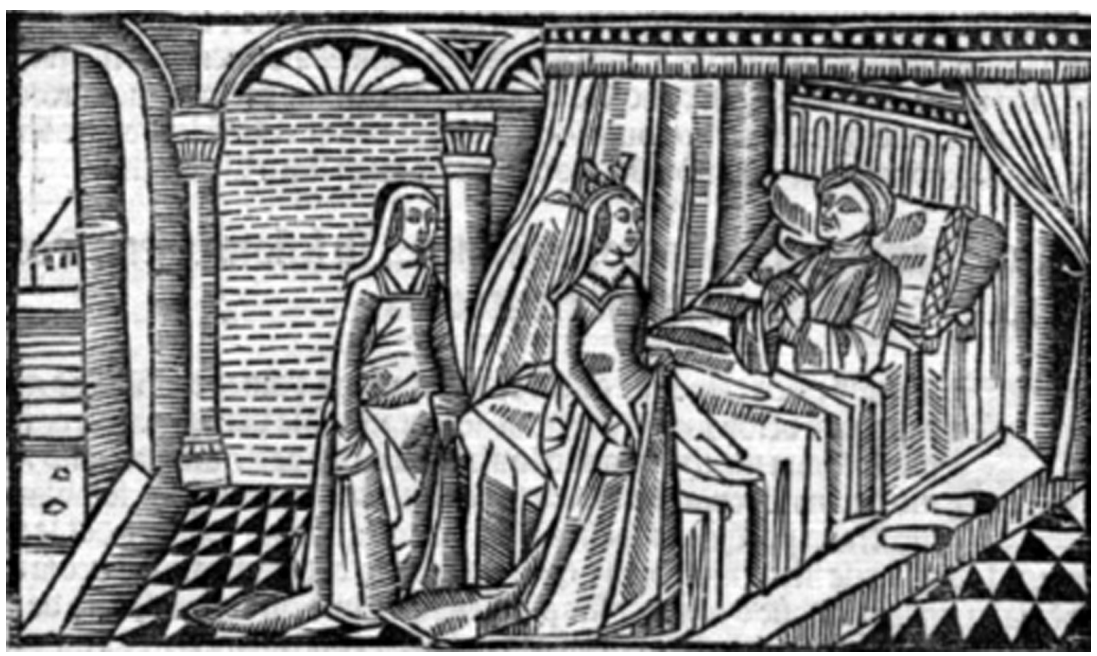

Fig. 13.

Versión española de la Fig. 7, que presenta a Oliveros, enfermo de amor, visitado por Helena (Oliveros de Castilla, Fadrique de Basilea, Burgos, 1499).

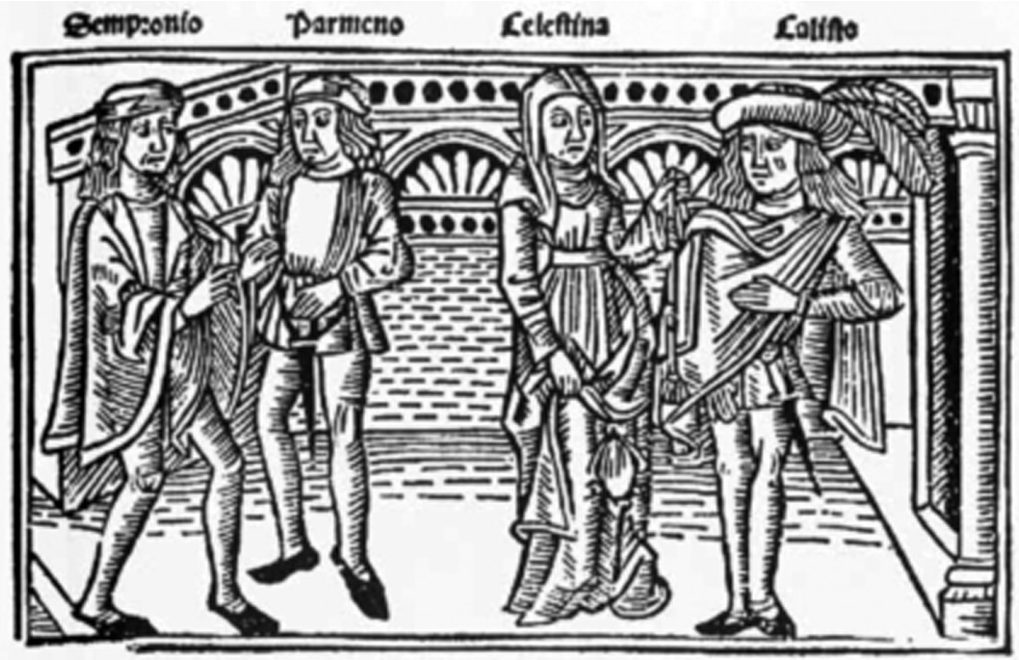

Fig. 14.

Celestina da el cordón de Melibea a Calisto en su casa en presencia de Pármeno y Sempronio (acto seis de La Celestina, Fadrique de Basilea, Burgos, 1499). Nótese el parecido de las cristalera con las de las Fig. 12 y 13. 


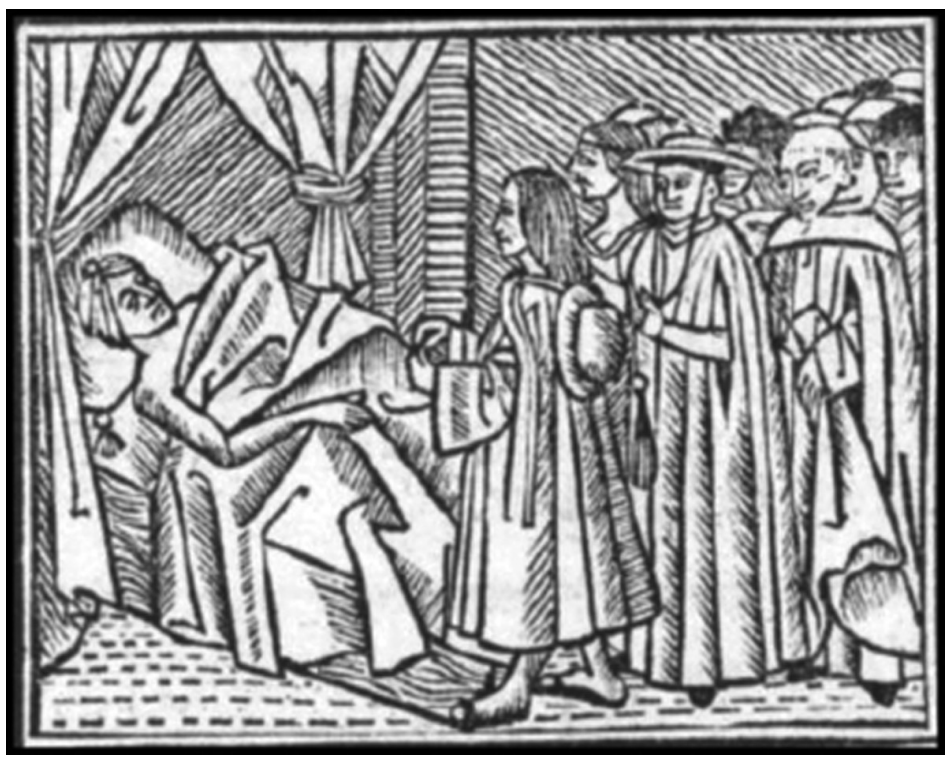

Fig. 15.

Grabado repetido tres veces en la edición del Oliveros de Castilla de Cromberger (Sevilla, 1507) para ilustrar el nacimiento de Oliveros, la enfermedad de Artús y la venida de Oliveros a curarlo con la sangre de sus hijos.

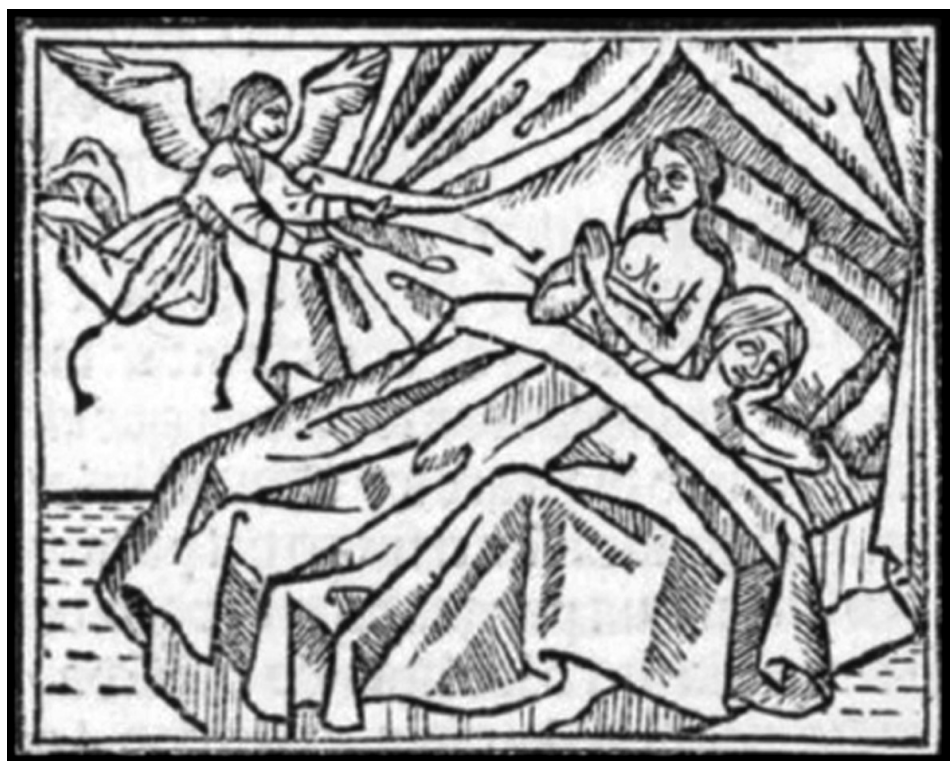

Fig. 16.

Boda de la hija de Oliveros con el rey del Algarve (Oliveros de Castilla, Cromberger, Sevilla, 1507). 



\section{FERnÁNDEZ RIVERA, Enrique, «Calisto, Leriano, Oliveros: tres dolien- tes y un mismo grabado", Celestinesca 36 (2012), pp. 119-142.}

\section{RESUMEN}

La mitad derecha del grabado que ilustra el acto trece de La Celestina de Burgos (1499) presenta a Calisto en la cama con la cabeza apoyada en la mano, imagen que está copiada del grabado de Leriano enfermo de amor de la edición de Cárcel de amor de Zaragoza (1493). A su vez, este grabado de Cárcel de amor está basado en otro de la obra francesa L'histoire d'Olivier de Castille (Basilea, 1493) que representa a Olivier enfermo de amor por la princesa Hélène. En la traducción al español, publicada también en Burgos en1499, Oliveros enfermo de amor aparece, curiosamente, vestido como Leriano en Cárcel de amor. Desde el punto de vista de la recepción de La Celestina en sus primeros años, la ascendencia de este grabado de un Calisto pensativo en la cama conecta la obra directamente con la novela sentimental y los libros de caballerías.

Palabras clave: Celestina, ilustraciones, grabados, Cárcel de amor, Oliveros de Castilla.

\section{ABSTRACT}

The right half of the engraving illustrating act thirteenth of the 1499 Burgos edition of Celestina depicts Calisto, in bed, resting his head on his hand. The image is taken from the depiction of the lovesick Leriano in the illustrated edition of Cárcel de amor (Zaragoza, 1493), which, itself, is taken from an engraving of L'histoire d'Olivier de Castille (Basilea, 1493) showing Olivier pining for Princess Hélène. Noticeably, in the Spanish translation of the adventures of Olivier (Burgos, 1499), a sick Oliveros wears the same clothes as Leriano in Cárcel de amor. From the point of view of the reception of Celestina in its first years, the origin of this engraving depicting a pensive and resting Calisto proves a direct connection with the sentimental novel and the books of chivalry.

KEY WORDS: Celestina, illustrations, engravings, Cárcel de amor, Olivier de Castille.

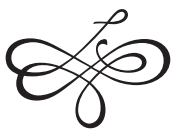

